\title{
Programa Saúde na Escola: intervenções para qualificação do programa de Atenção Básica realizadas no município de Petrópolis/Rio de Janeiro através de Residência Multiprofissional coordenada pela Faculdade Arthur Sá Earp Neto
}

\author{
Maycom Maia de Mello
}

\begin{abstract}
Resumo
O Programa Saúde na Escola (PSE) foi instituído em 2007 como estratégia articulada ao fortalecimento do programa Saúde da Família (Ministério da Saúde) a fim de fomentar a integração das redes de cuidado (saúde, educação, assistência etc.) através de ações de promoção, prevenção e atenção à saúde com vistas ao enfrentamento das vulnerabilidades que comprometem o pleno desenvolvimento de crianças e jovens. Tais ações devem estar atreladas, tanto para os profissionais da área de saúde quanto para os da educação, à ideia de que o desenvolvimento humano é sistêmico e atravessado por múltiplos fatores de ordem bio psico-socio-ambiental. Desta forma, torna-se imperativo ampliar o conceito de saúde e bem-estar para além da tradicional noção de que saúde é apenas "ausência de doenças" a fim de potencializar intervenções que promovam melhorias na qualidade de vida humana (tanto na esfera individual quanto na esfera coletiva). Alicerçado por tais prerrogativas, um dos psicólogos da equipe de profissionais inseridos na rede de atenção básica em saúde do município de Petrópolis/RJ, através da $1^{\text {a }}$ turma de Residência Multiprofissional coordenada pela Faculdade Arthur Sá Earp Neto, implementou durante o $2^{\circ}$ semestre de 2015, em duas escolas de um bairro da $3^{a}$ região daquele município, um ciclo de intervenções de caráter continuado, direcionadas aos alunos do ensino fundamental, com vistas ao resgate simbólico do espaço escolar enquanto local privilegiado para promoção de saúde e integração coletiva. Através da técnica "rodas de conversa" os alunos foram instigados a refletirem e a debaterem sobre temas por eles selecionados (bullying, sexualidade, prevenção ao uso de drogas, perspectivas de futuro profissional etc.) tendo como contraponto do psicólogo facilitador duas perguntas base: "Em que medida as características do território/comunidade onde você está inserido interferem nos temas abordados?" e "Qual papel você desempenha na sua história e na história dos seus coletivos?". Assim, ainda que o produto das intervenções não possa ser quantitativamente mensurado, aposta-se na eficácia da estratégia utilizada, mobilizadora de um espaço de escuta e fala horizontalizadas e de valorização de saberes na qual os participantes são estimulados a se reconhecerem como sujeitos da própria história, implicados na investigação das próprias vulnerabilidades biopsicossociais e na apropriação de práticas saudáveis de autocuidado e de autogestão. O episódio em que uma das agentes comunitárias da UBSF local, após atuar como co-facilitadora em alguns encontros, revelou ao psicólogo o desejo (mais tarde concretizado) de retornar os estudos por ter identificado em si mesma novas potencialidades profissionais, aliado à solicitação expressa pela direção escolar de que os trabalhos não fossem interrompidos no semestre seguinte, corroboram a relevância e o sucesso do projeto piloto realizado (que no ano seguinte teve continuidade através de nova turma de profissionais do programa de residência inseridos naquela região, assegurando, assim, a integração e articulação permanentes entre equipes de saúde e educação, conforme preconizado pelo Ministério da Saúde).
\end{abstract}

Descritores: Programa Saúde na Escola; Psicologia; Atenção Básica 